\title{
Temporal variation of bird assemblages in dynamic fluvial wetlands: seasonality and influence of water level and habitat availability
}

\author{
Rodrigo E. Lorenzón ${ }^{1 *}$, Adolfo H. Beltzer ${ }^{1}$, Pamela F. Olguin ${ }^{1}$, Evelina J. León ${ }^{1}$, \\ Lorena V. Sovrano ${ }^{1}$, Carolina E. Antoniazzi ${ }^{1}$ \& Ana L. Ronchi-Virgolini ${ }^{2}$ \\ 1. Instituto Nacional de Limnología (INALI-CONICET-UNL), Santa Fe (3000), Santa Fe, Argentina; \\ roylorenzon@gmail.com, adolfohec2001@yahoo.com.ar, pameolguin_06@hotmail.com, \\ evelinaleon903@hotmail.com, lorenavsovrano@hotmail.com, caroantoniazzi@gmail.com \\ 2. Universidad Autónoma de Entre Ríos (UADER), Oro Verde (3101), Entre Ríos, Argentina; 1ronchi@gmail.com \\ * Correspondence
}

Received 25-III-2019. C Corrected 24-VI-2019. Accepted 06-IX-2019.

\begin{abstract}
Introduction: Study of temporal variation of bird assemblages may be particularly important in highly dynamic ecosystems as fluvial wetlands to identify the factors that influence and contribute to maintain regional bird diversity. Objective: To study temporal variation in regional bird species composition (i.e. set of species that make up the assemblage) and richness (i.e. species number) and the factors that drive it, and quantify the importance of temporal-beta diversity to sustain bird regional diversity, in the fluvial system of the Middle Paraná River in Argentina. Methods: We sampled birds on a regional scale by performing 16 repeated surveys roughly every 45 days across 2 years (2011-2013) at 60 point counts distributed along the fluvial system. Results: We recorded a total of 162 species and 12738 detections, with a mean of $72.7 \pm 1.9$ species and $796.1 \pm 41$ individuals per survey. Temporal beta diversity accounted for $57 \%$ of regional bird species richness. Bird composition varied seasonally because of the species turnover (and not nestedness) between non-breeding and breeding periods; migrant species contributed to this issue but did not account for all these differences. Difference in bird composition between years was associated primarily to species turnover within non-breeding periods and was related to changes in water levels. Temporal variation in availability of habitats across the regional extent of the fluvial system accounted for the highest proportion of temporal beta diversity. Species richness neither varies seasonally nor was it related to fluctuations in water level or habitats. Conclusions: The climatic seasonality and environmental dynamics of the fluvial system, as a function of water-level fluctuations and of variations in habitat availability, jointly influence regional composition of birds through temporal species turnover. These variations in regional composition were not related to variations in regional species richness. These results show the importance of the natural dynamic of the fluvial system to preserve the processes that maintain the regional assemblage of birds.
\end{abstract}

Key words: Argentina; floodplain; nestedness; Paraná River; species turnover; temporal beta diversity.

Lorenzón, R. E., Beltzer, A. H., Olguin, P. F., León, E. J., Sovrano, L. V., Antoniazzi, C. E., \& Ronchi-Virgolini, A. L. (2019). Temporal variation of bird assemblages in dynamic fluvial wetlands: seasonality and influence of water level and habitat availability. Revista de Biología Tropical, 67(6), 1131-1145.

Fluvial ecosystems such as floodplains are among the most endangered ecosystems worldwide because of alterations in the hydrological dynamics of rivers caused by water-management activities and climate change (Tockner et al., 2008; Royan et al., 2015). Fluvial ecosystems are highly dynamic and heterogeneous with a shifting fine-grained mosaic of environments. Organisms that inhabit these ecosystems must respond to continuous variations in their 
habitat because of fluctuations in water levels of associated rivers (Royan et al., 2015; Bodmer et al., 2018). Understanding the responses of organisms to constant fluctuations in their habitat can contribute to an understanding of the importance of environmental dynamic to the maintenance of the regional biodiversity of fluvial systems.

Birds are among the most conspicuous and abundant vertebrates of fluvial wetlands, characteristics that have made them a key group for understanding the process that are occurring within fluvial ecosystems and further to know where and how to put conservation efforts for these systems (Davis, 1994). Different species use the mosaic of environments of fluvial wetlands in different ways, adjusting their use in accordance with the changing dynamics of these systems (Kingsford, Jenkins, \& Porter, 2004; Lorenzón, Beltzer, Olguin, \& Ronchi-Virgolini, 2016). Despite their importance, studies about the relationships between bird assemblages and hydrological regimes of fluvial wetlands are still very scarce (e.g. Knutson \& Klass, 1997; Kingsford et al., 2004; Cumming, Paxton, King \& Beuster, 2012; Bodmer et al., 2018).

Climatic seasonality can drive temporal variation of bird assemblages in fluvial wetlands. Specifically, because of the effects of climatic seasonality over resources abundance and habitat structure (e.g. by phenological changes in the vegetation) (Wiens, 1992; Ippi, Anderson, Rozzi, \& Elphick, 2009). In addition to general phenological changes in the environment caused by climatic seasonality, hydrological fluctuations are important in fluvial wetlands because of their effects on the dynamic of these systems (Junk, Bayley, \& Sparks, 1989). Hydrological fluctuations drive changes in habitat availability for birds, affecting bird abundance and accessibility to resources (Knutson \& Klass, 1997; Kingsford et al., 2004; Cumming et al., 2012). Because the hydrological dynamics of fluvial wetlands, as well as effects of climatic seasonality, are reflected in the habitats for birds that provide these systems (Stanford, Lorang, \& Hauer,
2005; Lorenzón et al., 2017), different aspects of the temporal dynamics of habitats may account for the temporal variation of bird assemblages in these environments.

Hydrologic dynamics of fluvial systems can be considered as an environmental filter because it reduces the regional pool of species to a subset that occurs locally (e.g. species that tolerate fluctuations in water levels) (Boulton et al., 2008). High mobility of birds, however, can allow them to use fluvial wetlands opportunistically and to abandon them when conditions are not optimal, such as during flood pulses. Thus, bird species richness (i.e., species number) may decrease temporarily during high-water seasons because fluvial habitats remain temporarily inaccessible to species that cannot tolerate flooded conditions (Beltzer \& Neiff, 1992; Knutson \& Klass, 1997; Poiani, 2006). Accordingly, water-level fluctuations could drive patterns of temporal nestedness of bird assemblages (i.e. temporal variation of species richness instead of species turnover). However, species composition (i.e. set of species that make up the assemblage) can vary because water-level fluctuations generate different habitat combinations (e.g. more open water and less beach habitat during highwater seasons) that different bird species use opportunistically according to their habitat requirements. Thus, this temporal variation in the availability of habitats may drive temporal turnover of bird species.

In this work, we studied temporal variation in the regional bird species composition and species richness in fluvial wetlands of the Paraná River, a relatively undisturbed fluvial system and the second largest river in South America (Nestler, Baigún, Oldani, \& Weber, 2007). We assessed the relationships of this temporal variation of bird assemblages with climatic seasonality, water-level fluctuations and variation of habitats by perform 16 repeated surveys every $\sim 45$ days across two years (2011-2013) at 60 point counts distributed along the fluvial system. We assessed the importance of climatic seasonality, water-level fluctuations and habitat availability to explain 
the temporal patterns in i) regional bird species composition and ii) regional bird species richness, iii) whether temporal-beta diversity (i.e. variation in composition among surveys) is related to temporal species turnover, temporal nestedness (i.e. temporal variation in alpha diversity or species richness because of gain and elimination of species among surveys) or both, and iv) the contribution of alpha (i.e. species richness per survey) and temporal-beta diversity to regional (gamma) diversity.

\section{MATERIALS AND METHODS}

Study area: Our study system includes the middle section of the Paraná River (Fig. 1), a fluvial corridor that begins at the confluence of the Paraguay and Paraná rivers $\left(27^{\circ} 17^{\prime} 00^{\prime \prime}\right.$ $\left.\mathrm{S} \& 58^{\circ} 38^{\prime} 00^{\prime \prime} \mathrm{W}\right)$ and extends $\sim 600 \mathrm{~km}$ to the beginning of the Paraná River Delta $\left(32^{\circ} 04^{\prime} 00^{\prime \prime} \mathrm{S} \& 60^{\circ} 38^{\prime} 00^{\prime}\right.$ " W) (Nestler et al., 2007). The middle section of the Paraná River has a well-developed floodplain composed by streams and seasonally flooded islands. Islands show a gradient in vegetation from the highest areas that are dominated by woods to lower areas dominated by shrubs, herbaceous plants, and open water (Sabattini \& Lallana, 2007). The environments in which we conducted our samples included shrub swamps and marshes. These environments are dominated by shrubs and herbaceous plants that can tolerate hydric

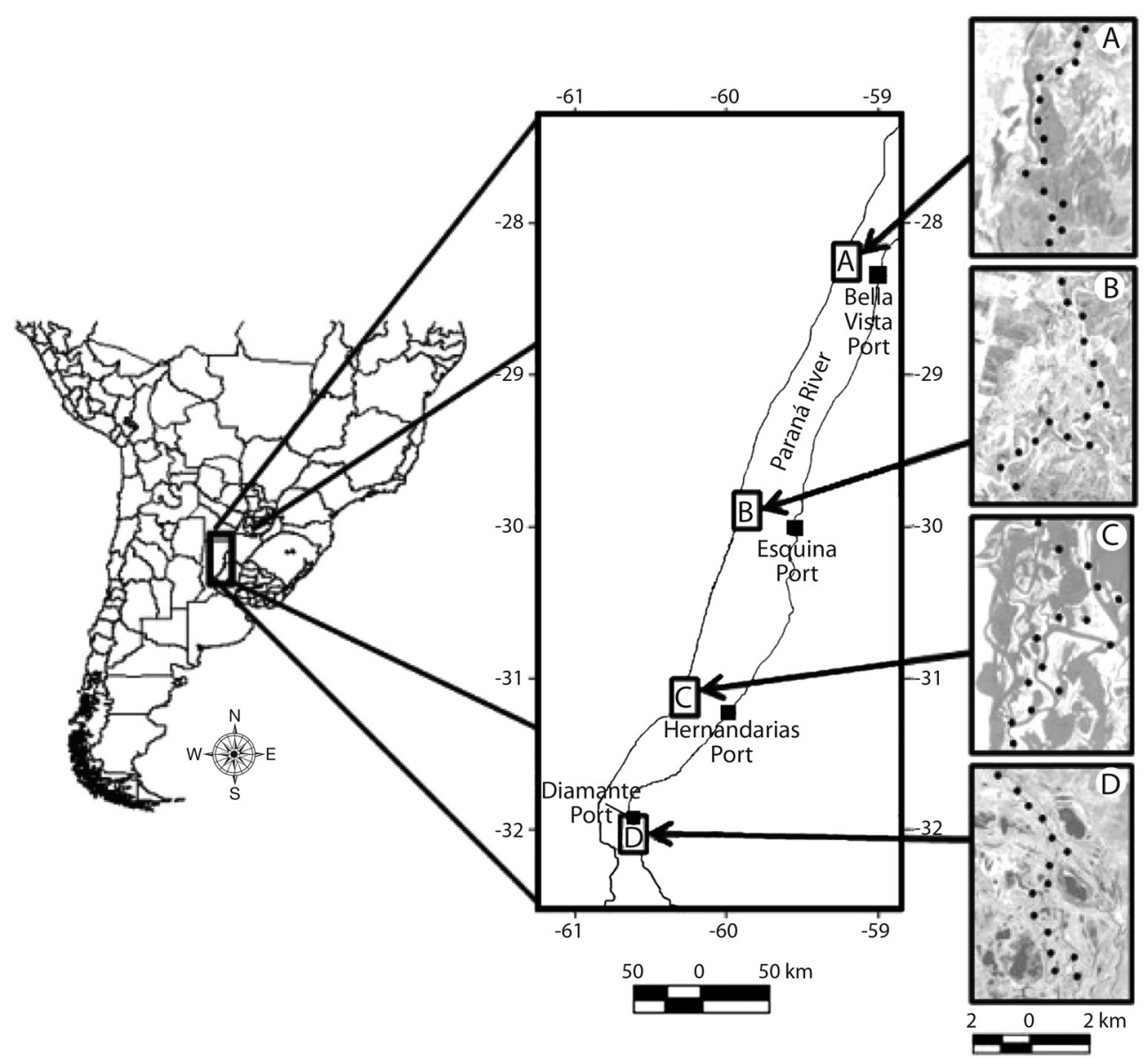

Fig. 1. Location of Middle Paraná River in the southern cone of South America showing four study areas (A, B, C, D), distribution of point counts within each study area (black circles) and the four ports (black squares) from which water-level data were obtained. Taken from Lorenzón et al. (2017). 
soils due to permanent (water bodies) or periodic (intermediate areas) presence of water, which varies with topographic height and the influence of the hydrological pulse (Sabattini \& Lallana, 2007; Lorenzón et al., 2017). The climate is subtropical humid in the northern areas, where average annual temperature is $21^{\circ} \mathrm{C}$ and annual rainfall is $1100 \mathrm{~mm}$ (Cáceres, 1980), shifting to temperate humid in the southern areas (Iriondo, Paggi, \& Parma, 2007), where average annual temperature is $19{ }^{\circ} \mathrm{C}$ and average annual rainfall is $900 \mathrm{~mm}$ (Rojas \& Saluso, 1987). Climate presents a marked intra-annual seasonality through four seasons: autumn (March to June), winter (June to September), spring (September to December) and summer (December to March), with warmer temperatures and more rainfall during spring-summer (September to March) than in autumn-winter (March to September) periods (Appendix 1). Autumn-winter and spring-summer periods correspond to the non-breeding and breeding periods, respectively, for birds. Throughout the manuscript, we assessed the temporal variation of the bird assemblages as a function of these two levels: four climatic seasons (autumn, winter, spring and summer) nested within two reproductive periods (non-breeding and breeding), taking into account that, despite these differences, both levels reflect the climatic seasonality of the study area. The typical hydrometric regime is characterized by a high-water period in summer-autumn (December-April) and a low water period in early spring (September-October) (Giacosa, Paoli, \& Cacik, 2000).

Bird sampling: We sampled birds at four study areas distributed along the Middle Paraná River to represent the full extent of this fluvial system (Fig. 1). Within each area, birds were sampled by 15 point counts repeated roughly every 45 days during 2 years from 2011 to 2013; two counts per season, four seasons per year or 16 surveys per area. We systematically located point counts in a North-South direction along waterways to ensure accessibility under different hydrological conditions of the river. Point counts were separated by at least 800 $\mathrm{m}$ to obtain independent counts. Point counts were located along the sides (relative to the course of Paraná River) of the floodplain in shrub swamps and marshes. All birds seen and heard within a radius of $100 \mathrm{~m}$ from the centre of each point were recorded during a 10-min sampling period (Ralph et al., 1996). We used a relatively large radius because counts were conducted in open areas with good visibility. We used range-finders for distance determinations. Bird counts began at sunrise and continued for 4 hours, a period of greater stability in terms of detecting birds (Robbins, 1981). Counts were performed by the same observer (REL) in all cases (see Lorenzón et al., 2017 for more details on location of point counts and sampling technique).

Water-level metrics: We used data on river water levels as a measure of hydrological fluctuations. Fluctuations of the water level were characterized by records from ports on the Paraná River located in each of the four study areas. Water levels obtained from these ports have been shown to be associated with different biological processes of the fluvial system, including spatial and temporal patterns of birds (Beltzer \& Neiff, 1992; Lorenzón et al., 2017). We used the water levels recorded on the same date as the bird surveys (16 records at four localities $=64$ water-level measures). Water levels were averaged among the four study areas to obtain a water level for each of the 16 surveys. Considered in this way, water levels reflected the hydrological state of the fluvial system at a regional scale according to the combination of the 60 point counts per survey to obtain an estimate of the composition and structure of bird assemblages in this scale of analysis (see Bird composition section below).

Habitat metrics: We used structural characteristics to classify habitats by vegetation type or other types of land cover when vegetation was absent. Types of habitats were: (i) open water; (ii) floating macrophytes (e.g. Eichhornia spp., Pistia stratiotes and Salvinia spp.); (iii) emergent macrophytes (e.g. Polygonum 
acuminatum, Sagittaria montevidensis); (iv) shrublands (e.g. Solanum glaucophyllum, Sesbania virgata); (v) grazed pastures; (vi) beach, which included both sand beaches and mudflats; and (vii) grasslands, dominated by Coleataenia prionitis. We refer to these environmental units as habitats throughout the manuscript because each of these is used by a different set of bird species. Thus, we use "habitat" as a term that refers to a particular environmental unit, discernible from other units, which represents the space shared by several species (Di Bitetti, 2012). The proportion of covered area by each habitat type was estimated through direct field observations during each survey (i.e. 16 times) within 200-m radius (range-finders were used to determine distance) from the centre of each point count. Proportions of covered area by each type of habitat were summed among the 60 point counts per survey. Thus, we obtained a measure of covered area for each habitat at regional scale, according with bird and water level data. This information on habitat composition was used to calculate the Pielou's evenness of the habitat types per survey as measure of evenness of habitats. In addition, we averaged the number of habitats per point count to obtain a measure of habitat heterogeneity per survey.

\section{Data analysis:}

- $\quad$ Temporal patterns in regional bird species composition: We used a non-metric multidimensional scaling (NMDS) to assess how was the variation in bird composition (i.e. list of species and their relative abundances) among the 16 surveys and to what extent this variation was related to the climatic seasonality. Abundances for each species were summed among the 60 point counts in each survey (i.e. NMDS was based in 16 samples, Appendix 2). Through this aggregation, we eliminated variation related to spatial differences among point counts basing the analysis on an estimate of the abundance of each species at a regional scale. This reduces the influence of local movements on the temporal patterns (Wiens, 1992) and greatly contributed to the clarity of the analysis because it allowed us to focus only on the temporal variation of the data. The NMDS ordination was created using the 'metaMDS' function in the vegan package (Oksanen et al., 2015) for R (R Core Team, 2017). The matrix of bird relative abundances (Appendix 2) was squareroot transformed and relativized through Wisconsin double standardization where species abundances are first standardized by maxima and then point counts by point count totals (Oksanen, 2011). The ordination was evaluated by the coefficient of determination based on stress $\left(\mathrm{R}^{2}\right)$ (Oksanen, 2011). Permutational multivariate analysis of variance (PERMANOVA) was used to test for differences in composition per survey between climatic seasons within non-breeding (i.e. autumn and winter seasons) and breeding (i.e. spring and summer seasons) periods ("strata" argument of adonis function was used to constrain permutations within reproductive periods), between non-breeding and breeding periods and between years. The bird dissimilarity matrix was based on the Bray-Curtis index in the NMDS and PERMANOVA analysis.

To describe the relationship of the bird ordination to the changes in water level and habitats, we overlaid these variables on the NMDS plot by 'envfit' analysis of the vegan package (Oksanen et al., 2015). The 'envfit' function fits vectors of environment variables onto an ordination such that projections of points onto vectors have maximum correlation. Goodness-of-fit of vector was assessed by the squared correlation coefficient $\left(\mathrm{R}^{2}\right)$. Significance of goodness-of-fit was assessed by permutations (999). PERMANOVA was used to test for differences in bird composition per survey as a function of water level and habitat variables and to test whether 
habitat composition per survey varied as a function of water level. Dissimilarity matrix of habitats between surveys was created using Euclidean distances. Association between temporal variation of water-level fluctuations and relative areas of each habitat was assessed using Spearman's correlation coefficient (rho). These analyses were performed through $\mathrm{R}$ ( $\mathrm{R}$ Core Team, 2017) using vegan package (Oksanen et al., 2015).

Variation-partitioning analysis performed by vegan package ("varpart" function) in R (R Core Team, 2017) was performed to partition temporal variation in bird composition per survey with respect to non-breeding and breeding periods (sensu NMDS ordination), water-level fluctuations, habitats variables and their combination. Explained variation was estimated through the adjusted R-squared to control for number of variables in each set of predictors (Peres-Neto, Legendre, Dray, \& Borcard, 2006), in distance-based redundancy analysis (dbRDA, with bird dissimilarity calculated by Bray-Curtis index). Significance of the overall dbRDA model and of individual fractions were evaluated by permutation tests ( 999 permutations).

- $\quad$ Temporal patterns in regional bird species richness: Temporal patterns of regional bird species richness (i.e. accumulated species richness among the 60 point counts per survey) was assessed by comparing this variable among the 16 surveys by calculating $95 \%$ confidence intervals (95 $\%$ Cis) (Eq. 6 in Colwell, Mao, \& Chang, 2004). This analysis assumes that the species richness of a sampling set (60 point counts in our study) is measured with error and as such, is possible to calculate an estimate of the variance and CIs (Colwell et al., 2004). These calculations were performed using the EstimateS (version 9.1.0) software (Colwell, 2016). Non-overlapping CI's indicate a significant difference among surveys. Spearman's correlation coefficient was used to assess the similarity of the temporal variation of species richness i) between overall, migrant and resident assemblages, and ii) with temporal variation of habitats and water-level.

- Decomposition of temporal-beta diversity in turnover and nestedness components: Contribution of temporal species turnover and temporal nestedness (i.e. elimination or addition of species among surveys) to temporal-beta diversity (i.e. temporal variation of bird composition) was assessed by the decomposition of pairwise Sorensen index into those components using package betapart (Baselga \& Orme, 2012) in R ( $\mathrm{R}$ Core Team, 2017). This decomposition of temporal-beta diversity was performed by comparing bird assemblages between non-breeding and breeding periods, and between non-breeding periods of the first and second year, because the greatest differences in composition occurred between these periods according with results of the NMDS ordination.

- Contribution of alpha and temporal-beta diversities to regional diversity: Relative importance of alpha diversity (i.e. species richness per survey) and temporalbeta diversity (i.e. compositional changes among surveys) in shaping regional (gamma) diversity was assessed through an additive model: gamma diversity $=$ alpha diversity + beta diversity (Lande, 1996). We performed this analysis to quantify the importance of temporal beta-diversity to sustain the regional species richness. Additive partitions of diversity decompose gamma diversity into alpha and beta components that can be compared because they are expressed in the same units (number of species in our study) (Crist, Veech, Gering, \& Summerville, 2003). Although based on this additive model the temporalbeta diversity is measured as number of species, this number is a measure of the 
magnitude of the compositional changes among surveys. This analysis was performed among the 16 surveys and, according to the results of the NMDS ordination, within non-breeding and breeding periods to assess whether temporal-beta diversity still was important within these periods. We used R (R Core Team, 2017) and package vegan (Oksanen et al., 2015) for the calculation of diversity partitions.

\section{RESULTS}

General results: We recorded a total of 162 species and 12738 detections, with a mean of $72.7 \pm 1.9$ species and $796.1 \pm 41$ detections per survey. A total of 135 species and 6630 detections were recorded during the non-breeding period ( $\mathrm{n}=8$ surveys) and a total of 134 species and 6108 detections were recorded during the breeding period ( $n=8$ surveys). There were 130 species $(80 \%)$ and 11785 detections (93\%) of resident birds and 32 species $(20 \%)$ and 953 detections $(7 \%)$ of migrant birds. Twenty-one species $(13 \%)$ were recorded in all surveys and 24 species (15\%) were recorded in only one survey (Appendix 2).

Temporal patterns in regional bird species composition: The first dimension of the NMDS (Stress $=0.15$ ) largely reflected differences in bird composition between nonbreeding and breeding surveys (Fig. 2). This seasonal separation was related to the presence of migrant species that are present in the area principally during non-breeding (e.g. Asthenes pyrroleuca, Phytotoma rutila, Cinclodes fuscus) or during breeding (e.g. Butorides striata, Volatinia jacarina, Tyrannus savana) periods. The second dimension reflected differences in surveys between the first and second year but only within non-breeding periods. For example, Phalacrocorax brasilianus, Ciconia maguari and Himantopus mexicanus were more common in the first year whereas Calidris fuscicollis, Mimus saturninus, and Troglodytes aedon

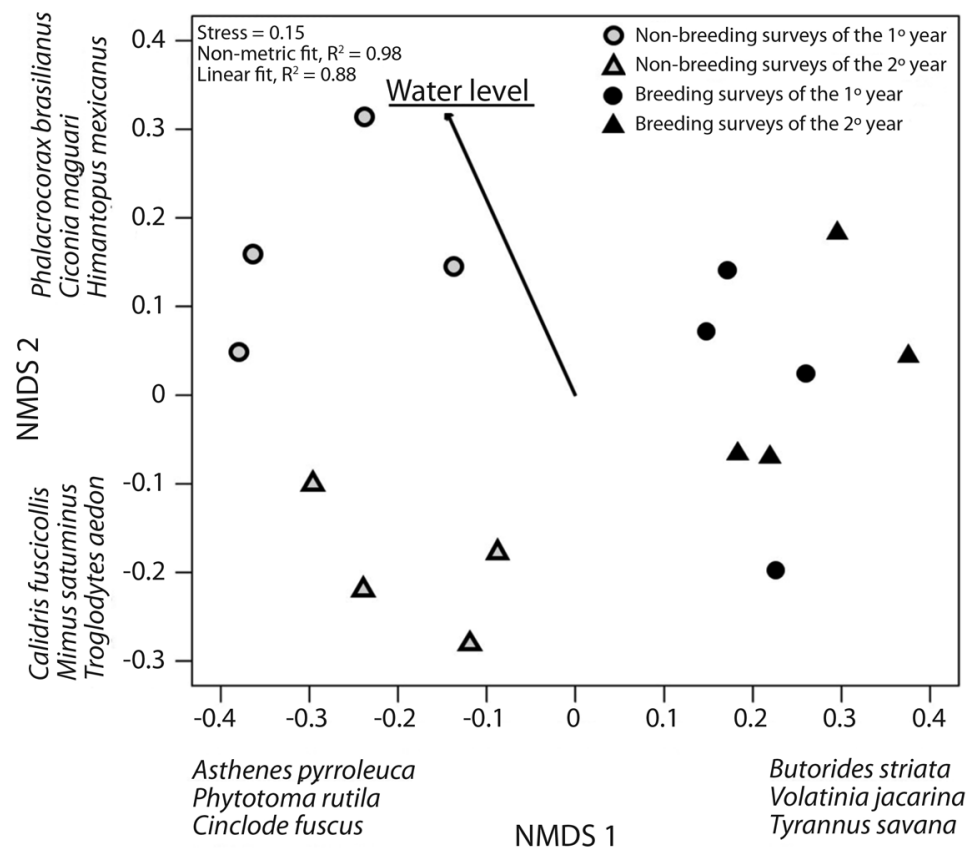

Fig. 2. Non-metric multidimensional scaling (NMDS) ordination of bird species composition among the 16 surveys performed from 2011-2013. Bird relative abundances in each survey were based on the aggregation of abundances across 60 point counts located along the fluvial system. Water level of the river was fit on ordination results by envfit function. Some of the bird species most strongly associated with the dimensions are indicated. 
were more common in the second year (Fig. 2). Based on the NMDS, species composition did not differ between climatic seasons within nonbreeding and breeding periods (i.e. autumn vs winter and spring vs summer, PERMANOVA, $\mathrm{R} 2=0.30, \mathrm{~F} 3,12=1.7, \mathrm{P}=0.673$ ) but did differ between non-breeding and breeding periods (PERMANOVA, R2 = 0.20, F1, $14=3.4, \mathrm{P}=$ 0.001 ) and between years (PERMANOVA, R2 $=0.15 ; \mathrm{F} 1,14=2.5, \mathrm{P}=0.014)$. Between-year differences were significant only within nonbreeding periods (PERMANOVA, R2 $=0.41$, $\mathrm{F} 1,6=4.1, \mathrm{P}=0.032)$; there were no betweenyear differences for breeding periods (PERMANOVA, R2 $=0.17, \mathrm{~F} 1,6=1.3, \mathrm{P}=0.194$ ). Resident bird species as a group showed the same patterns as the overall bird assemblage, reflecting that residents accounted for most species and detections along surveys.

The 16 water levels corresponding to each survey date ranged between 2.5 and $5.2 \mathrm{~m}$ (mean $\pm \mathrm{SE}=3.4 \pm 0.2 \mathrm{~m}$, Appendix 3). Based on the NMDS ordination, changes in water levels accounted for much of the difference in bird species composition between the non-breeding periods of the first and second year of the study (Envfit, $\mathrm{R}^{2}=0.56, \mathrm{P}=0.005$ ). Surveys during the first year experienced higher water levels (mean $=4.1 \pm 0.82 \mathrm{~m}$; maximum: $5.15 \mathrm{~m}$ in the 1 st survey) than during the second year ( 3.3 $\pm 0.7 \mathrm{~m}$; maximum: $4.2 \mathrm{~m}$ in the 10 th survey, Appendix 3). After accounting for differences between reproductive periods, composition varied as a function of water level (PERMANOVA, $\mathrm{R}^{2}=0.10, \mathrm{~F}_{1,13}=1.8, \mathrm{P}=0.046$ ).

Habitat composition of the fluvial system varied among surveys as a function of water level (PERMANOVA, $\mathrm{R}^{2}=0.20, \mathrm{~F}_{1,14}=3.5, \mathrm{P}$ $=0.018)$. Increased water levels were associated with increases in the total area of open water (Spearman, rho $=0.63, \mathrm{P}=0.009$ ) and floating macrophytes (Spearman, rho $=0.54, \mathrm{P}=0.032$ ) and with a reduction in beach areas (Spearman, rho $=-0.52, P=0.037)$. Higher water levels had a marginally significant effect on the evenness of habitats (Spearman, rho $=-0.49, \mathrm{P}=0.052$ ). Area of shrublands, emergent macrophytes, grazed pastures, grasslands and the number of different habitats were not associated with water-level fluctuations (Spearman, $\mathrm{P}>0.1$ in all cases). The fit of each individual habitat type on the NMDS-based bird ordination did not account for the temporal arrangement of the surveys (Envfit, $\mathrm{P}>0.1$ in all cases).

Survey reproductive period, water-level fluctuations and habitat availability accounted for $43 \%$ of temporal variation in regional bird species composition (dbRDA, $\mathrm{F}_{9,4}=1.6, \mathrm{P}=$ 0.011 , Fig. 3). Survey reproductive period and water level still showed a significant influence on the temporal variation in species composition after accounting for effects of habitats types $\left(\mathrm{dbRDA}, \mathrm{R}^{2}=0.24, \mathrm{~F}_{2,4}=2.1, \mathrm{P}=\right.$ 0.045 ), although the individual effect of these variables was marginal (Period, dbRDA, $\mathrm{R}^{2}=$ $0.16, \mathrm{~F}_{1,4}=2.4, \mathrm{P}=0.059$ ) or not significant (water level, dbRDA, $\mathrm{R}^{2}=0.8, \mathrm{~F}_{1,4}=1.7, \mathrm{P}$ $=0.183$ ). Habitats types considered together accounted for $24 \%$ of temporal variation in bird composition (dbRDA, $\mathrm{F}_{9,4}=1.6, \mathrm{P}=$ 0.020 ). A remaining $9 \%$ of temporal variation in bird species was related to habitat variation both between reproductive periods and as a function of water-level fluctuations (Fig. 3).

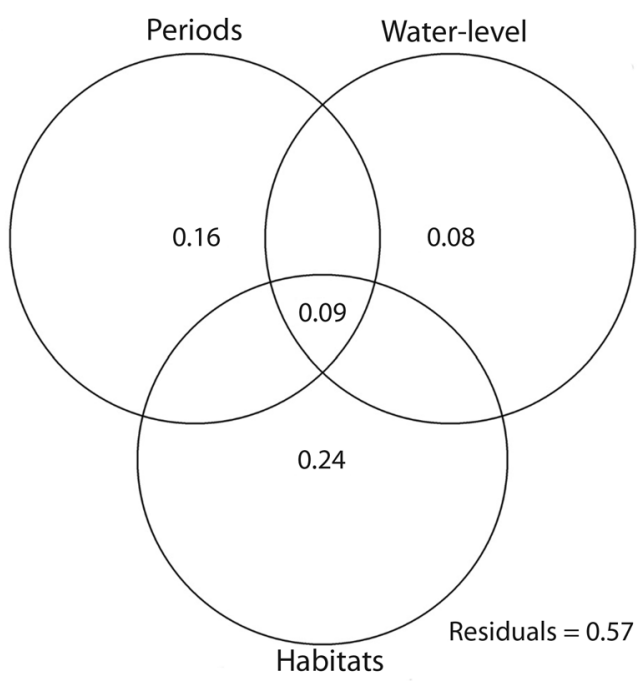

Fig. 3. Variation partitioning of the effects of breeding and non-breeding periods, water-level fluctuations and habitats on temporal variation of regional bird composition along the extension of the Middle Paraná River. 


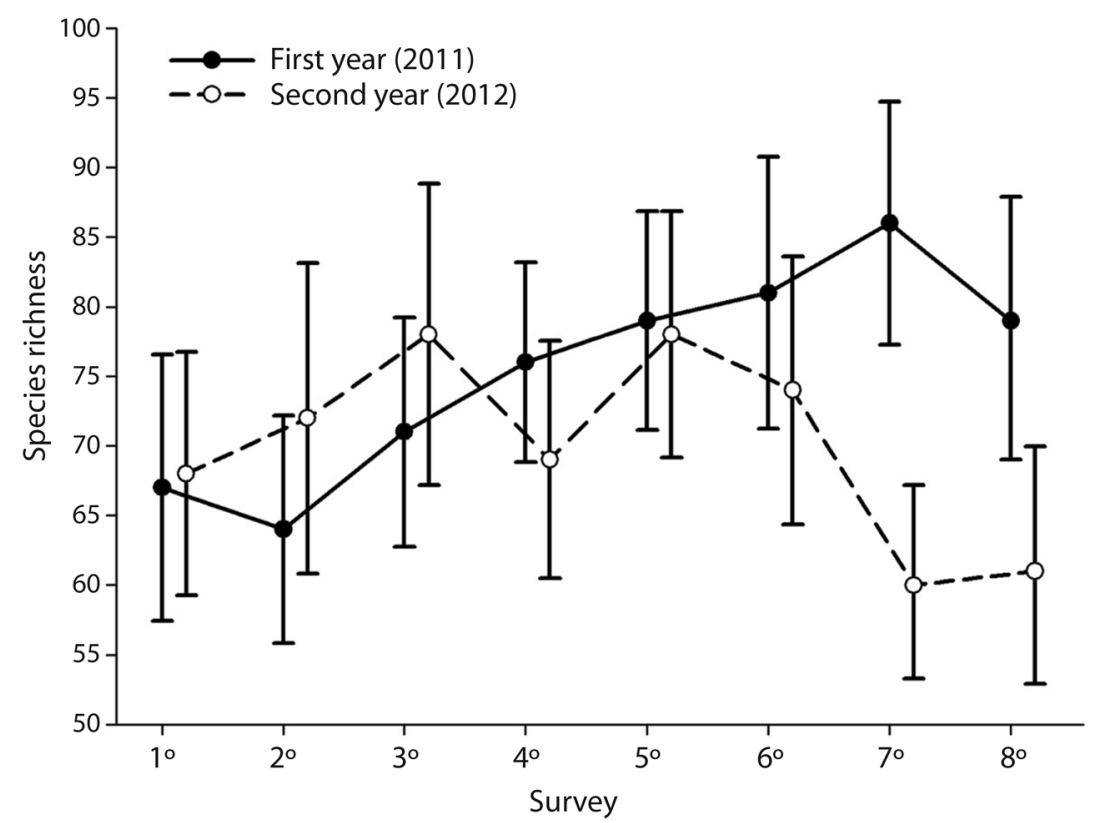

Fig. 4. Observed species richness $\pm 95 \%$ CIs in each of the eight surveys of the first and second years. Species richness in each survey is based on the accumulation of recorded species across 60 point counts located along the fluvial system.

Temporal patterns in regional bird species richness: Species richness varied among 8 surveys within the first year, with higher species richness in the 7th survey (summer season) than in the $1^{\text {st }}$ and $2^{\text {nd }}$ surveys (autumn season; $95 \%$ CIs of species richness by survey did not overlap among these surveys, Fig. 4). In contrast, species richness did not vary among 8 surveys within the second year (Fig. 4). Species richness did not vary between the paired surveys of the first and second year with exception of the higher species richness recorded in the 7th survey of the first year than in the 7th survey of the second year (Fig. 4). Temporal variation in species richness across surveys was not correlated between years (Spearman, rho $=$ $-0.05, \mathrm{P}=0.885$ ).

Temporal variation in species richness was positively associated with variation in the number of migrant species (Spearman, rho $=0.65, \mathrm{P}$ $=0.001)$ and, even more strongly, with number of resident species (Spearman, rho $=0.82, \mathrm{P}$ $<0.001)$. Variation in overall species richness and number of resident species among the 16 surveys were not associated with variation in water levels (Spearman, rho $=-0.23, \mathrm{P}=$ 0.399 and rho $=-0.19, \mathrm{P}=0.478$, respectively). Similarly, variation of species richness was not correlated with area of any type of habitat or with the number and evenness of habitat types (Spearman, $\mathrm{P}>0.05$ in all cases).

Decomposition of temporal-beta diversity in turnover and nestedness components: Differences between non-breeding and breeding periods were related mostly to species turnover (Pairwise-mean $\beta_{\text {sim }}=0.34$ ) rather than nestedness-related dissimilarity (Pairwisemean $\left.\beta_{\text {sne }}=0.04\right)$. Differences in composition between the non-breeding periods of the first and second year were related mostly to species turnover (Pairwise-mean $\beta_{\text {sim }}=0.31$ ) while nestedness-related dissimilarity presented a lower value (Pairwise-mean $\beta_{\text {sim }}=0.03$ ).

Contribution of alpha and temporalbeta diversities to regional diversity: Alpha (i.e. species richness per survey) and temporalbeta diversity accounted for 73 species (45\%) and 89 species (55\%) of the total, respectively. 
Alpha and temporal-beta diversity accounted for 71 species $(53 \%)$ and 64 species $(47 \%)$, respectively, during non-breeding surveys $(\mathrm{n}=$ 8 surveys). Corresponding numbers during the breeding periods were 75 species $(56 \%)$ and 59 species (44\%), respectively.

\section{DISCUSSION}

Temporal environmental variability can promote species diversity because it can increase the accumulated number of species over time by increase the temporal species turnover (White, Ernest, Adler, Hurlbert, \& Lyons, 2010). This may be particularly important in highly dynamic systems as fluvial ecosystems where hydrological fluctuations continuously modify habitat conditions creating significant environmental variability over time. To test these ideas in the Middle Paraná fluvial system, we study the temporal variation of the regional bird species composition and species richness and their relationship with the environmental variations of this system. We found an effect of climatic seasonality because bird assemblages showed a seasonal pattern with bird composition showing species turnover between non-breeding (autumn-winter) and breeding (spring-summer) periods. However, we also found that variations in water level may generate species turnover (and not nestedness) within non-breeding periods between years, increasing temporal-beta diversity. In addition, our results suggest that an important proportion of these changes in bird composition at regional scale are related to habitat dynamics of the fluvial system. These changes in composition, however, were not associated with temporal changes in regional species richness, variable that was not related to any of the environmental variations considered. As a result of environmental fluctuations, we found that the temporal species turnover accounted for a significant proportion - $\sim 50 \%$ - of the total species richness (i.e., accumulated species number among the 16 surveys) of the fluvial system.
Temporal patterns in regional bird composition: The regional approach adopted allowed us to obtain relevant temporal patterns because of the relatively large area covered during each survey by which we include a great environmental heterogeneity in each one. We sampled birds over a wide area with substantial environmental heterogeneity in each survey by sampling 60 point counts over approximately $450 \mathrm{~km}$ along the fluvial system. The high environmental heterogeneity included in each survey allowed us to sample a high number of spatial niches of the fluvial wetlands, which have been shown to be good predictors of the bird composition of the system (Lorenzón, Beltzer, Olguin, \& Ronchi-Virgolini, 2016). The relatively large sample size reduced effects of sampling error on estimates of temporal beta diversity (i.e. the failure to detect species that were actually present). Thus, although increasing the spatial extent of sampling can reduce temporal beta diversity (McGlinn \& Palmer, 2009), that component of diversity still was important in establishing regional species richness (i.e. gamma diversity of birds in this fluvial system).

Our results suggested a joint influence of climatic seasonality and hydrological fluctuations on temporal patterns of bird composition. These joint influence can be stablished because, although part of the temporal beta diversity was related to seasonal changes between nonbreeding and breeding periods, after excluding effects of seasonality by considering only surveys within each of these periods, temporal beta diversity remained important, representing approximately 44 to $47 \%$ of total species richness.

Temporal patterns of composition found in this study suggest that the most important effects of climatic seasonality over bird assemblages are related to differences between nonbreeding and breeding periods (and not among the four climatic seasons). This seasonality of assemblages reflected migratory movements of birds. Migratory species (32 species) remain 
in the area principally during non-breeding or breeding periods with no species present exclusively during autumn, winter, spring or summer. Although some species reproduce, a set of migrant species have their wintering grounds during the months corresponding to the breeding period. Thus, migrant species helped to account for the differences in bird assemblages between non-breeding and breeding periods and for the relative similarity in assemblages between the climatic seasons within these periods. Thus, composition of bird assemblages in fluvial wetlands of the Paraná River showed a seasonality related with migratory patterns of bird species, as has been found in previous studies across both upland (Codesido \& Bilenca, 2004; Kelt et al., 2012) and wetland ecosystems of South America (Blendinger \& Alvarez, 2002; Ronchi-Virgolini, Lorenzón, Blake, \& Beltzer, 2013).

Resident species also showed seasonal variation in composition between non-breeding and breeding periods. This suggests that, although resident species do not perform regular movements outside the region, movements within the region, between habitats within the fluvial system, and between the fluvial system and the uplands, influence the composition of bird assemblages in fluvial wetlands. These movements suggest important environmental variation between non-breeding and breeding periods because such movements may be reflecting than birds are tracking resources availability (e.g., food, habitats) (Wiens, 1992).

Differences in bird composition within non-breeding periods between the two years of this study were related to changes in water levels given that high water levels during March and April in 2011 flooded a large proportion of the floodplain. Although there also were increases in water levels in other months, including during the second year, none were of such duration and magnitude. The water level of this flood pulse was above $5 \mathrm{~m}$ for 69 days in 2011 at locality A (Fig. 1) but was above 5 $\mathrm{m}$ for only nine days in 2012 . This hydrological pattern, with alternating years with general low water levels and another one with general high water levels are representative of the hydrological variability of the system recorded in the last 30 years (Marchetti, Latrubesse, Pereira, \& Ramonell, 2013). These variations in the water level can drastically change habitats and resource availability for different species (Kingsford et al., 2004; Cumming et al., 2012), ultimately modifying the regional composition of birds of the fluvial system.

Temporal variation in composition of habitats across the regional extent of the fluvial system accounted for the highest proportion of temporal variation in bird species composition. The great dynamics of fluvial wetlands are reflected in variation over time in the extent and distribution of habitats (Stanford et al., 2005). For birds, temporal variation in composition of habitats across the fluvial system can be related to climatic seasonality (e.g. by phenological variation in vegetation), and with the direct influence of water level over habitat availability (e.g. terrestrial habitats may be temporarily flooded). Variation partitioning analysis showed that temporal variation of bird assemblages that was related to differences in habitat composition between periods was also related to water-level fluctuations. This could be related with the seasonal basis of the waterlevel fluctuations, and its influence on habitats, because the most important increase in water level occurred principally during the first nonbreeding period. Much of the variation in species composition was accounted for habitat variation (24\%), however, it was independent of reproductive period and was not related with water level. These non-seasonally structured habitat changes could be related to other drivers of habitat variation within fluvial wetlands (e.g. erosion and deposition of sediments, regeneration of riparian vegetation) (Stanford et al., 2005) that are not reflected by the river water levels during each survey.

General temporal patterns of bird composition were related to species turnover rather than to nestedness, which does not support the idea that temporal variation in fluvial wetlands can be driven by temporal reductions in bird assemblages to a subset of flood-tolerant 
species. Instead, our results suggest that temporal variation is driven by species turnover between non-breeding and breeding periods as a function of habitat and water-level fluctuations. Temporal species turnover as a function of water-level fluctuations could reflect the high mobility of birds. Environment variability may account for compositional turnover through time if species with different requirements are favoured as prevailing conditions change (Chesson \& Huntly, 1997; Shurin, 2007). High mobility allows birds to use fluvial wetlands in an opportunistic fashion, leaving the habitats when the conditions are unfavourable and recolonizing when the environmental conditions are appropriate again (Cumming et al., 2012). Thus, as habitat conditions of the fluvial wetlands change, different species are favoured, generating patterns of species turnover over time.

Temporal patterns in regional bird species richness: We did not find a seasonal pattern in regional species richness because temporal patterns were different between years. Thus, variation in species richness was not associated with the seasonality found in regional bird species composition. Although this absence of differences contrasts with bird studies in the Neotropic that have found a higher species richness during breeding periods (i.e., spring-summer months; e.g. Romano, Barberis, Pagano, \& Maidagan, 2005; Ippi et al., 2009; Ronchi-Virgolini, Blake, Lorenzón, \& Beltzer, 2011), others studies conducted in neotropical wetlands have not found differences in species richness between reproductive periods or climatic seasons (Brandolin, Martori, \& Ávalos, 2007; Aynalem \& Bekele, 2008; Ronchi-Virgolini et al. 2013), according to our results.

Temporal variation in species richness of the entire bird assemblage partially reflected variation in the number of migrant species among years. However, migrants did not account for temporal variation in species richness because resident species had a greater impact on total species richness. This suggests that movements performed by resident species may drive the temporal variation of regional species richness. These movements may include displacements between the different habitats within fluvial system (e.g. displacements towards fluvial forests), between the fluvial systems and the uplands and regional movements of birds toward other wetlands and along the fluvial corridor (Antas, 1994; Sullivan, Watzin, \& Keeton, 2007).

We did not find a correlation between species richness, water level and number of habitats. Thus, although habitat heterogeneity accounts for the spatial variation of species richness at the local scale (Lorenzón et al., 2016), this variable did not explain temporal variation in the regional richness of the fluvial system.

Final considerations: Our results show that climatic seasonality in the form of nonbreeding (autumn-winter) and breeding (spring-summer) periods, water level and habitat fluctuations of the river-floodplain system of the Paraná River may drive cyclical turnover of species over time because of temporal environmental heterogeneity. Thus, climatic seasonality, water level and habitat fluctuations may generate and maintain the regional pool of species that can inhabit the fluvial system during different temporal frameworks. An understanding of temporal patterns and underlying processes of bird assemblages in floodplain systems can help demonstrate the importance of hydrological variability to bird conservation because this show how this hydrological variation sustain bird diversity of these systems.

Ethical statement: authors declare that they all agree with this publication and made significant contributions; that there is no conflict of interest of any kind; and that we followed all pertinent ethical and legal procedures and requirements. All financial sources are fully and clearly stated in the acknowledgements section. A signed document has been filed in the journal archives. 


\section{ACKNOWLEDGMENTS}

This work was supported by the Consejo Nacional de Investigaciones Científicas y Técnicas (CONICET) under Grant PIP 0463 and Francois Vuilleumier Fund 2008 (Neotropical Ornithological Society). We thank the Meteorological Information Center "Lic. Enrique Rodriguez" from the Facultad de Ingeniería y Ciencias Hídricas (UNL) for providing the water-level data. We are grateful to John G. Blake for English editing and constructive comments on the drafts of this paper.

\section{RESUMEN}

Variación temporal de ensambles regionales de aves en humedales fluviales dinámicos: estacionalidad e influencia del nivel de agua y la disponibilidad de hábitat. Introducción: El estudio de la variación temporal de los ensambles de aves es particularmente importante en ecosistemas altamente dinámicos como los humedales fluviales para identificar los factores que influencian y contribuyen al mantenimiento de la diversidad regional. Objetivo: Se estudió la variación temporal de la composición (i.e. conjunto de especies que componen el ensamble) y riqueza (número de especies) regional de aves, junto con los factores que las conducen, y la importancia de la diversidad-beta temporal para mantener la riqueza regional de aves, en el sistema fluvial del río Paraná Medio en Argentina. Metodología: Se muestrearon aves a escala regional mediante la realización de 16 muestreos repetidos aproximadamente cada 45 días durante 2 años (2011-2013) en 60 puntos de conteo distribuidos a lo largo del sistema fluvial. Resultados: Se registraron un total de 162 especies y 12738 detecciones, con una media de $72.7 \pm 1.9$ especies y $796.1 \pm 41$ detecciones por muestreo. La diversidad beta temporal representó el 57 \% de la riqueza regional de especies. La composición de aves varió estacionalmente debido al recambio (y no al anidamiento) de especies entre períodos no-reproductivos y reproductivos; la variación temporal de las especies migrantes contribuyó, pero no explicó estas diferencias. La diferencia en la composición de aves entre años fue debido al recambio de especies dentro de los períodos no-reproductivos; ese recambio se relacionó con variaciones en el nivel de agua del río. La variación temporal en la disponibilidad de hábitats a lo largo de la extensión regional del sistema fluvial se asoció con la más alta proporción de diversidad beta temporal. La riqueza de especies no varió estacionalmente ni se relacionó con las fluctuaciones en el nivel del agua o los hábitats. Conclusiones: La estacionalidad climática y la dinámica ambiental del sistema fluvial, en función de las fluctuaciones en el nivel de agua y de las variaciones en la disponibilidad de hábitat, influenciaron conjuntamente la composición regional de aves mediante el recambio temporal de especies. Estas variaciones en la composición regional no se relacionaron con variaciones en la riqueza regional de especies. Estos resultados muestran la importancia de la dinámica natural del sistema fluvial para conservar los procesos que mantienen el ensamble regional de aves.

Palabras clave: Argentina; planicie de inundación; anidamiento; río Paraná; recambio de especies; diversidad beta temporal.

\section{REFERENCES}

Antas, P. D. T. Z. (1994). Migration and other movements among the lower Paraná River valley wetlands, Argentina, and the south Brazil/Pantanal wetlands. Bird Conservation International, 4(2-3), 181-190. DOI: $10.1017 / \mathrm{S} 0959270900002768$

Aynalem, S., \& Bekele, A. (2008). Species composition, relative abundance and distribution of bird fauna of riverine and wetland habitats of Infranz and Yiganda at southern tip of Lake Tana, Ethiopia. Journal of Tropical Ecology, 49, 199-209.

Baselga, A., \& Orme, C. D. L. (2012). Betapart: an R package for the study of beta diversity. Methods in Ecology and Evolution, 3(5), 808-812. DOI: 10.1111/j.2041-210X.2012.00224.X

Beltzer, A. H., \& Neiff, J. J. (1992). Distribución de las aves en el valle del río Paraná. Relación con el régimen pulsátil y la vegetación. Ambiente Subtropical, $2,77-102$.

Blendinger, P. G., \& Alvarez, M. E. (2002). Ensambles de aves de los bañados de Carilauquen (Laguna Llancanelo, Mendoza, Argentina): consideraciones para su conservación. Hornero, 17(2), 71-83.

Brandolin, P., Martori, R., \& Ávalos, M. (2007). Variaciones temporales de los ensambles de aves de la reserva natural de fauna Laguna La Felipa (Córdoba, Argentina). Hornero, 22, 1-8.

Bodmer, R., Mayor, P., Antunez, M., Chota, K., Fang, T., Puertas, P., Pittet, M., Kirkland, M., Walkey, M., Rios, C., Perez-Peña, P., Henderson, P., Bodmer, W., Bicerra, A., Zegarra, J., \& Docherty, E. (2018). Major shifts in Amazon wildlife populations from recent intensification of floods and drought. Conservation Biology, 32(2), 333-344. DOI: 10.1111/cobi.12993

Boulton, A. J., Boyero, L., Covich, A. P., Dobson, M., Lake, P. S., \& Pearson, R. G. (2008). Are tropical streams ecologically different from temperate streams? In D. Dudgeon (Ed.), Tropical stream ecology (pp. 257-284). San Diego: Academic Press. DOI: 10.1899/08-146.1 
Cáceres, L. M. (1980). Caracterización climática de la provincia de Santa Fe. Santa Fe, Argentina: Departamento de Aguas, Ministerio Agricultura y Ganadería de Santa Fe.

Chesson, P., \& Huntly, N. (1997). The roles of harsh and fluctuating conditions in the dynamics of ecological communities. American Naturalist, 150(5), 519-553. DOI: $10.1086 / 286080$

Codesido, M., \& Bilenca, D. (2004). Variación estacional de un ensamble de aves en un bosque subtropical semiárido del Chaco Argentino. Biotropica, 36(4), 544-554. DOI: $10.1646 / 1595$

Colwell, R. K., Mao, C. X., \& Chang, J. (2004). Interpoling, extrapoling, and comparing incidence-based species accumulation curves. Ecology, 85(10), 2717 2727. DOI: $10.1890 / 03-0557$

Colwell, R. K. (2016). EstimateS: Statistical estimation of species richness and shared species from samples (Version 9.1.0). Retrieved from http://viceroy.eeb. uconn.edu/estimates

Crist, T. O., Veech, J. A., Gering, J. C., \& Summerville, K. S. (2003). Partitioning species diversity across landscapes and regions: a hierarchical analysis of $\alpha, \beta$ and $\gamma$ diversity. American Naturalist, 162(6), 734-743. DOI: $10.1086 / 378901$

Cumming, G. S., Paxton, M., King, J., \& Beuster, H. (2012). Foraging guild membership explains variation in waterbird responses to the hydrological regime of an arid-region flood-pulse river in Namibia. Freshwater Biology, 57(6), 1202-1213. DOI: 10.1111/j.1365-2427.2012.02789.x

Davis, T. J. (1994). The Ramsar Convention manual: a guide to the convention on wetlands of international importance especially as waterfowl habitat. Gland, Switzerland: Ramsar Convention Bureau.

Di Bitetti, M. S. (2012). ¿Qué es el hábitat? Ambigüedad en el uso de jerga técnica. Ecología Austral, 22, 137-143.

Giacosa, R., Paoli, C., \& Cacik, P. (2000). Conocimiento del régimen hidrológico. In C. Paoli, \& M. Schreider (Eds.), El río Paraná en su tramo medio (69-103). Santa Fe: Centro de Publicaciones UNL.

Ippi, S., Anderson, C. B., Rozzi, R., \& Elphick, C. S. (2009). Annual variation of abundance and composition in forest bird assemblages on navarino island, Cape Horn Biosphere Reserve, Chile. Ornitología Neotropical, 20(2), 231-245.

Iriondo, M. H., Paggi, J. C., \& Parma, M. J. (2007). The Middle Paraná River: limnology of a subtropical wetland. New York-Berlin: Springer.

Junk, W. J., Bayley, P. B., \& Sparks, R. E. (1989). The flood pulse concept in river-floodplain systems.
Canadian Journal of Fish Aquatic Science, 106(1), 110-127.

Kelt, D. A., Engilis, Jr. A., Monárdez, J., Walsh, R., Meserve, P. L., \& Gutiérrez, J. R. (2012). Seasonal and multiannual patterns in avian assemblage structure and composition in northern Chilean thorn-scrub. Condor, 114(1), 30-43. DOI: 10.1525/cond.2012.110036

Kingsford, R. T., Jenkins, K. M., \& Porter, J. L. (2004). Imposed hydrological stability on lakes in arid Australia and effects on waterbirds. Ecology, 85(9), 2478-2492. https://doi.org/10.1890/03-0470

Knutson, M. G., \& Klass, E. E. (1997). Declines in abundance and species richness of birds following a major flood on the Upper Mississippi River. Auk, 114(3), 367-380. DOI: $10.2307 / 4089239$

Lande, R. (1996). Statistics and partitioning of species diversity, and similarity among multiple communities. Oikos, 76(1), 5-13. DOI: 10.2307/3545743

Lorenzón, R. E., Beltzer, A. H., Olguin, P. F., \& RonchiVirgolini, A. L. (2016). Habitat heterogeneity drives bird species richness, nestedness and habitat selection by individual species in fluvial wetlands of the Paraná River, Argentina. Austral Ecology, 41(7), 829-841. DOI: $10.1111 /$ aec. 12375

Lorenzón, R. E., Beltzer, A. H., Peltzer, P. M., Olguín, P. F., León, E. J., Sovrano, L., \& Ronchi-Virgolini, A. L. (2017) Habitat-mediated influence of waterlevel fluctuations on waterbird occurrence in floodplain wetlands of the Parana River, Argentina. River Research and Applications, 33(9), 1494-1505. DOI: 10.1002/rra.3199

Marchetti, Z. Y., Latrubesse, E. M., Pereira, M. S., \& Ramonell, C. G. (2013). Vegetation and its relationship with geomorphologic units in the Parana River floodplain, Argentina. Journal of South American Earth Science, 46, 122-136. DOI: 10.1016/j. jsames.2013.03.010

McGlinn, D. J., \& Palmer, M. W. (2009). Modelling the sampling effect in the species-time-area relationship. Ecology, 90(3), 836-846. DOI: 10.1890/08-0377.1

Nestler, J. M., Baigún, C. R., Oldani, N., \& Weber, L. J. (2007). Contrasting the Middle Paraná and Mississippi Rivers to develop a template for restoring large floodplain river ecosystems. International Journal of River Basin Management, 5(2), 305-319. DOI: $10.1080 / 15715124.2007 .9635329$

Oksanen, J. (2011) Multivariate Analysis of Ecological Communities in $R$ : vegan tutorial. Retrieved from http://cc.oulu.fi/ jarioksa/opetus/metodi/vegantutor. pdf

Oksanen, J., Blanchet, F. G., Kindt, R., Legendre, P., O’Hara, R. B., Simpson, G. L, ... Wagner, H. (2015). Vegan: Community Ecology Package (Version 2.3-0). 
Retrieved from https://cran.r-project.org/web/packages/vegan/vegan.pdf

Peres-Neto, P. R., Legendre, P., Dray, S., \& Borcard, D. (2006). Variation partitioning of species data matrices: estimation and comparison of fractions. Ecology, 87(10), 2614-2625.

Poiani, A. (2006). Effects of floods on distribution and reproduction of aquatic birds. Advances in Ecological Research, 39, 63-83. DOI: 10.1016/ S0065-2504(06)39004-6

R Core Team. (2017). R: A language and environment for statistical computing. Version 3.4.2. Vienna, Austria: R Foundation for Statistical Computing.

Ralph, C. J., Geupel, G. R., Pyle, P., Martin, T. E., DeSante, D. F., \& Milá, B. (1996). Manual de métodos de campo para el monitoreo de aves terrestres. Gen. Tech. Rep. PSW-GTR-159-Web. Washington DC.: USDA Forest Service.

Robbins, C. S. (1981). Effect of time of day on bird activity. Studies in Avian Biology, 6, 275-286.

Rojas, A. E., \& Saluso, J. H. (1987). Informe climático de la provincia de Entre Ríos (Publicación técnica, 14). Paraná, Entre Ríos, Argentina: INTA EEA.

Romano, M., Barberis, I., Pagano, F., \& Maidagan, J. (2005). Seasonal and interanual variation in waterbird abundance and species composition in the Melincué saline,lake, Argentina. European Journal of Wildlife Research, 51, 1-13. DOI: 10.1007/ s10344-005-0078-Z

Ronchi-Virgolini, A. L., Blake, J. G., Lorenzón, R. E., \& Beltzer, A. H. (2011). Bird assemblages in two types of forests in the floodplain of the lower Paraná River (Argentina). Ornitología Neotropical, 22, 387-404.

Ronchi-Virgolini, A. L., Lorenzón, R. E., Blake, J. G., \& Beltzer, A. H. (2013). Temporal variation of bird assemblages in a wetland: influence of spatial heterogeneity. Avian Biology Research, 6(3), 198-206.

Royan, A., Prudhomme, C., Hannah, D. M., Reynolds, S. J., Noble, D. G., \& Sadler, J. P. (2015). Climateinduced changes in river flow regimes will alter future bird distributions. Ecosphere, 6(4), 1-10. DOI: 10.1890/ES14-00245.1

Sabattini, R. A., \& Lallana, V. H. (2007). Aquatic macrophytes. In M. H. Iriondo, J. C. Paggi, \& M. J. Parma (Eds.), The Middle Paraná River (pp. 205-226). Berlin Heidelberg: Springer.

Shurin, J. B. (2007). How is diversity related to species turnover through time? Oikos, 116(6), 957-965. DOI: 10.1111/j.0030-1299.2007.15751.x

Stanford, J. A., Lorang, M. S., \& Hauer, F. R. (2005). The shifting habitat mosaic of river ecosystems. Int Ver Für Theor Angew Limnol Verhandlungen, 29(1), 123136. DOI: $10.1080 / 03680770.2005 .11901979$

Sullivan, S. M. P., Watzin, M. C., \& Keeton, W. S. (2007). A riverscape perspective on habitat associations among riverine bird assemblages in the Lake Champlain Basin, USA. Landscape Ecology, 22(8), 11691186. DOI: 10.1007/s10980-007-9097-3

Tockner, K., Bunn, S. E., Gordon, C., Naiman, R. J., Quinn, G. P., \& Stanford, J. A. (2008). Flood plains: critically threatened ecosystems. In N. V. C. Polunin (Ed.), Aquatic Ecosystems (pp. 45-61). Cambridge: Cambridge University Press.

Wiens, J. A. (1992). The ecology of bird communities (Vol. 2). Cambridge: Cambridge University Press.

White, E. P., Ernest, S. M., Adler, P. B., Hurlbert, A. H., \& Lyons, S. K. (2010). Integrating spatial and temporal approaches to understanding species richness. Philosophical Transactions of the Royal Society B: Biological Sciences, 365(1558), 3633-3643. DOI: 10.1098/rstb.2010.0280 